BIOMEDICAL AND BIOSOCIAL ANTHROPOLOGY
$\begin{gathered}\text { Official Journal of the International Academy } \\ \text { of Integrative Anthropology } \\ \text { journal homepage: http://bba-journal.com }\end{gathered}$

\title{
Correlation of indicators of cerebral blood circulation with anthropometric dimensions in practically healthy young men of ectomorphic somatotype
}

Datsenko G. V.', Smolko D. G. ${ }^{1}$, Makarchuk I. M.', Slabyy O. B. ${ }^{2}$, Prokopenko S. V. ${ }^{1}$

${ }^{1}$ National Pirogov Memorial Medical University, Vinnytsya, Ukraine

${ }^{2}$ SIHE "I. Ya. Horbachevsky Ternopil State Medical University of the Ministry of Health of Ukraine", Ternopil, Ukraine

\section{ARTICLE INFO}

Received: 6 September, 2018

Accepted: 9 November, 2018

UDC: $616-073.7: 616-$

071.2:613.99(477.44)

\section{CORRESPONDING AUTHOR}

e-mail: dgalina1808@gmail.com

Datsenko G. V.
In modern scientific literature, the vast majority of studies are devoted to the study of the features of cerebral circulation in representatives of different age-sex groups, but studies devoted to the constitutional features of cerebral hemodynamics in practically healthy population are practically absent. The purpose of the work is to establish correlation of indicators of cerebral blood circulation with anthropo-somatotypological parameters of the body in practically healthy young men of Podillia with ectomorphic somatotype. On the base of the research center of the National Pirogov Memorial Medical University, Vinnytsya conducted rheoencephalographic, anthropometric and somatotypological studies of 24 practically healthy urban young men from the Podillia region of Ukraine of ectomorphic somatotype. The correlation analysis was performed using Spearman nonparametric method in the licensed statistical package "Statistica 6.1". In practically healthy young men of the ectomorphic somatotype, the following multiple correlations of cerebral blood flow parameters with constitutional parameters of the body are established: direct reliable ( $r$ from 0.41 to 0.52) and unreliable mean power ( $r$ from 0.30 to 0.38 ) correlations of most amplitude indices with girth of the head and the largest length of the head, as well as the reverse, mostly unreliable ( $r$ from -0.30 to -0.40), and a reliable average power ( $r$ from - 0.41 to -0.53) correlations with most of the total body size, half of the width distal epiphyses long tubular bones of the limbs (WDE), the majority of the circumference of the extremities, third indicators thickness of skin and fat folds (TSFF), performance component composition weight; direct, mostly unreliable, average strength ( $r$ from 0.33 to 0.38 ) correlations of the duration of the cardiac cycle and the time of the downward part of the rheogram with a half of the TSFF indices; direct, mostly unreliable, average strength ( $r$ from 0.30 to 0.37) correlations of the dicrotic index with a third of the indices of the TSFF and the endomorphic component of the somatotype, as well as the inverse of the reliable ( $r$ from -0.40 to -0.58) and unreliable mean force ( $r$ from -0.30 to -0.40 ) correlations of the average speed of fast and slow blood filling with all total, half of the longitudinal body sizes, half of the WDE indexes, the majority of circumferential body sizes, more than half the body diameters, most of the indicators of the TSFF, the endomorphic component of the somatotype and all the components of the body composition and the reverse, mostly reliable, average strength ( $r$ from - 0.41 to -0.51) correlations of the index of tone of all arteries, the tone of the arteries of the large, as well as the middle and shallow diameters with more than half of the indices of the TSFF and the endomorphic component somatotype. In the analysis of correlations of rheoencephalogramms indicators with constitutional parameters of the body in practically healthy young men of the ectomorphic somatotype, the largest number, mostly inverse of reliable and unreliable mean strength correlations, was established for amplitude indices - with total body sizes $(66.7 \%$ of the total number of these indicators), indicators of component body composition (60.0\%), WDE (45.0\%), circumferential dimensions of the body (34.7\%), cephalometric indices (34.3\%) and TSFF (33.3\%). The largest number, mostly inverse, of reliable and unreliable average strength correlations, was found for the derived indicators - with TSFF $(47.2 \%$ of the 
total number of these indicators), somatotype components (29.2\%), components of body mass (28.1\%), total sizes body and WDE (25.0\%); and, mostly direct, inaccurate average strength correlations, for time indicators was established - with cephalometric indices $(28.6 \%$ of the total number of these indicators), TSFF (22.2\%) and body diameters (14.3\%).

Keywords: correlations, rheoencephalography, anthropometry, ectomorphic somatotype, practically healthy young men.

\section{Introduction}

Cerebrovascular diseases remain one of the most urgent medical and social problems. The incidence, disability and mortality of this pathology progressively increase with each subsequent decade. In connection with this, the nosologies associated with the lack of cerebral circulation have been isolated in an independent section of neuropathology - angio-neurology, and this problem is currently extremely important in medical and social significance $[8,15]$.

For now, vascular lesions of the brain have traditionally been regarded as the fate of persons of older age groups $[12,31]$. It is now clear that this point of view is not true. In recent years, a broader circle of researchers has observed a sharp increase in cerebral vascular disorders in children and young people. A number of scholars [2, 9, 15] indicate that approximately $12 \%$ of acute cerebrovascular disorders occur in people aged 15-45, making up the most common cause of neurological problems in this age group.

The problems of timely diagnosis and treatment of cerebrovascular diseases at the early and pre-nosological stages of their formation, when the most effective treatment and preventive measures [15, 29], are extremely important. The lack of reference functional criteria for assessing cerebrovascular flow and the standards of individual parameters of the human body cause difficulties in the diagnosis and treatment of such patients.

The leading criteria for the state of cerebral vessels are functional parameters of the cerebral circulation, determined by means of rheoencephalography. The state of cerebral vessels reflects the combined variability of their morphofunctional parameters at different stages of ontogenesis [4, 21, 22, 24]. Moreover, a certain constitutional type is characterized not only by the features of its morphofunctional organization, but also by their reactivity [23, 24, 25].

From the clinical point of view, the consideration of covariances of rheoencephalographic parameters with anthropometric parameters of the patient has a significant role as predictors in the diagnosis of acute and chronic cerebrovascular disorders [2, 19]. The number of complex studies and the comparison of the results of this problem is quite limited [3, 6, 17, 18, 27], so it requires a special study, both from the anatomical and anthropological point of view, and from the clinical and diagnostic.

The purpose of the work is to establish correlations of indicators of cerebral blood circulation with anthroposomatotypological parameters of the body of practically healthy young men of Podillia with ectomorphic somatotype.

\section{Materials and methods}

Rheoencephalographic, anthropometric and somatotypological studies of 143 practically healthy young men aged from 17 to 21 years, in the third generation residents of the Podillia region of Ukraine conducted on the basis of the research center of National Pirogov Memorial Medical University, Vinnytsya. The Bioethics Committee of the National Pirogov Memorial Medical University, Vinnytsya found that the research materials did not deny the basic bioethical norms of the Helsinki Declaration, the Council of Europe Convention on Human Rights and Biomedicine (1977), the relevant provisions of the WHO and the laws of Ukraine.

The rheoencephalography was performed using a computer diagnostic complex [33]. The anthropometric study, according to the scheme of Bunak V. V. [10], included the determination of total, longitudinal, circumferential body dimensions, body diameters (body size and pelvic size), width distal epiphyses of long tubular bones of the limbs (WDE) and thickness of skin-fatty folds (TSFF). Cephalometry included determination of head girth, sagittal arc, greatest length and width of the head, smallest head width, face and mandible width [1]. The components of the somatotype and the type of somatotype were determined according to the method of Carter J. and Heath B. [11], and the components of the body weight were measured by the method of Matiegka J. [20] and the American Institute of Nutrition (AIN) [28].

The analysis of correlations of cerebral blood flow with anthropometric and somatotypological parameters of young men of ectomorphic somatotype $(n=24)$ was performed using the nonparametric Spearman method in the licensed statistical package "Statistica 6.1".

\section{Results}

In the practically healthy young men of the ectomorphic somatotype, the following reliable and average strength false correlation of the parameters of cerebral circulation with constitutional parameters of the body are established:

basic impedance - a reliable strong reverse $(r=-0.64)$ correlations with the intertrochanteric pelvic size; reliable mean reciprocal force ( $r$ from -0.41 to -0.53 ) correlations with forearm girth in the lower third, with transverse midsternal size, TSFF on the back of the shoulder, with bone mass by Matiegka, as well as an unreliable average force straight $(r=0.39)$ correlations with the smallest head width; unreliable mean reverse ( $r$ from -0.30 to -0.40 ) correlations with total body size, WDE of shoulder, with neck, waist and 
brush girth, with TSFF on the forearm, under the shoulder blade, on the chest, with fat mass by Matiegka;

duration of the heart cycle - a reliable average power straight $(r=0.42)$ correlations with the TSFF on the tibia, as well as the unreliable mean force ( $r$ from 0.33 to 0.38 ) correlations with the TSFF on the abdomen, side, thigh;

the duration of the ascending part - a reliable average force straight $(r=0.43)$ correlations with the head girth; reliable mean reciprocal force $(r=-0.42)$ correlations with the greatest head width, as well as unreliable mean force straight ( $r$ from 0.30 to 0.38 ) correlations with the width of the face, waist circumference, foot, chest on the inhalation, with transverse mid-sternal size, shoulder width, with intertrochanteric pelvic size;

the duration of the downstream part - the true average strength straight ( $r$ from 0.41 to 0.46 ) correlations with the TSFF under the shoulder blade, the thigh and the tibia, as well as the unreliable mean power straight $(r=0.37$ in all cases) correlations with the TSFF on the abdomen, thigh, with the endomorphic component of the somatotype by HeathCarter;

the duration of the fast blood flow phase - reliable average power straight $(r=0.43)$ correlations with a transverse midsternal dimension, as well as an unreliable mean reciprocal force ( $r-0.30$ to -0.36 ) correlations with the smallest, largest width and sagittal arc of the head, with the girth of the thigh, the shin in the upper third, with the interspinous size of the pelvis;

the duration of the phase of slow blood filling - a reliable average force straight $(r=0.51$ and $r=0.48)$ correlations with the head girth and the width of the face; reliable mean reverse force $(r=-0.41)$ correlation with the forehead of the forearm, as well as the unreliable mean force straight $(r=$ 0.30 and $r=0.31$ ) correlations with the largest head width and abdominal TSFF;

the amplitude of the systolic wave - strong reverse ( $r=$ 0.65 ) correlations with the hip circumference; reliable mean force straight $(r=0.52)$ correlations with the greatest length of the head; reliable mean reciprocal force ( $r$ from -0.41 to 0.52) correlations with body weight, WDE of forehead, with shoulder girth in a tense and calm condition, interspinous size of the pelvis, with TSFF on the forearm, with muscle mass by Matiegka and for the AIN formula, as well as the unreliable mean power straight $(r=0.36$ and $r=0.39)$ correlations with the head circumference and the width of the mandible; unreliable mean reciprocal force ( $r$ from -0.30 to -0.38 ) correlations with the area of the body surface, with the shoulder and leg WDE, with the girth of the shin in the upper third, with the neckline, chest on the exhalation and in a calm condition girth, with transverse mid- and lower-sternal dimensions, TSFF on the front and back surfaces of the shoulder, with the TSFF on the chest, on the side, with the endomorphic component of the somatotype by Heart Carter and the fat mass by Matiegka;

incisure amplitude - the true mean power straight $(r=$ 0.43) correlations with the greatest length of the head; reliable mean reciprocal force ( $r$ from -0.45 to -0.52 ) correlations with the shoulder girth in a tense and calm condition, with a hip circumference, with a muscle mass by Matiegka and by the formula AIN, as well as an unreliable average force straight $(r=0.30)$ correlations with head circumference; unreliable mean reciprocal force ( $r$ from 0.30 to -0.39 ) correlations with body mass relation, with WDE of forearm, with upper leg girth, with transverse lower-sternal size, with mesomorphic component of the somatotype by Heath-Carter;

the amplitude of the diastolic wave - reliable average force straight $(r=0.46)$ correlations with the greatest length of the head; reliable mean reciprocal force ( $r$ from -0.43 to 0.53 ) correlations with shoulder girth in a tense and calm condition, with a hip circumference, with a muscle mass by Matiegka and the AIN formula, as well as an unreliable average force straight $(r=0.38)$ correlations with head circumference; unreliable mean reciprocal force ( $r$ from 0.30 to -0.37 ) correlations with the smallest head width, body weight, with the WDE of the forearm and the shin, with the upper leg girth over the upper third, with the transverse lowerthoracic size, with the TSFF on the back of the shoulder, on the forearm, chest, with mesomorphic component of the somatotype according to Heath-Carter;

the amplitude of the phase of rapid blood filling - a reliable strong reverse $(r=-0.68)$ correlations with the circumference of the thigh; reliable mean force straight $(r=$ 0.41 ) correlations with the greatest length of the head; reliable mean reciprocal force ( $r$ from -0.42 to -0.51 ) correlations with body weight, with WDE of the shin, with shoulder girth in a tense and calm condition, with an interspinous size of the pelvis, with muscle mass by Matiegka and according to the formula AIN, as well as the unreliable mean force straight $(r=0.31$ and $r=0.39)$ correlations with the head circumference and the width of the mandible; unreliable mean reciprocal force ( $r$ from -0.30 to -0.37 ) correlations with the length and area of the body surface, with the WDE of the shoulder, with the shin girth of the upper third, with the neck, brush, chest girth in calm condition, with the TSFF on the back shoulder surface, on the forearm, side, with bone mass by Matiegka;

dicrotic index - a reliable average power straight $(r=$ 0.41 ) correlations with the TSFF on the thigh; reliable mean reverse force $(r=-0.44)$ correlations with the greatest head width, as well as unreliable mean force straight ( $r$ from 0.30 to 0.37 ) correlations with the TSFF on the side, the tibia, with the endomorphic component of the somatotype by the HeathCarter;

diastolic index - only unreliable mean force straight $(r$ from 0.30 to 0.37 ) correlations with the hips, TSFF on the thigh and shin;

the average speed of the phase of rapid blood filling - a reliable average force straight $(r=0.52)$ correlations with the largest length of the head; reliable average reciprocal force ( $r$ from -0.41 to -0.58 ) correlations with total body size, WDE shoulder, forearm, shin, with shoulder girth in a tense and 
calm condition, with a girth of the thigh, neck, waist, chest on the exhalation and in a calm state, with transverse middlethoracic size, TSFF on the back of the shoulder, on the forearm, on the chest, on the side, with the endomorphic component of the somatotype according to Heath-Carter, all the components of the mass by Matiegka and with muscle mass, determined by the formula AIN, as well as unreliable mean reciprocal force ( $r$ from -0.30 to -0.39 ) correlations with the height of the suprasternal, shoulder and finger points, with the forearm circumference in the lower third, with the girth of the brush, the chest on the inhalation, with the transverse lower limb size and the anterior-posterior size of the chest, with the interspinous and intertrochanteric dimensions of pelvic, with TSFF on the front of the shoulder, under the shoulder blade, on the abdomen, thigh, shin;

average speed of the phase of slow blood flow - a reliable average power straight $(r=0.44)$ correlations with the greatest length of the head; reverse credible medium strength ( $r$ from -0.40 to -0.58 ) correlations with weight and body surface area, circumference of the arm in tight and rest, circumference of the thigh, lower leg in the upper third, neck and chest at rest with cross medium-sternal, interspinous sizes of the pelvis, with TSFF on the forearm with muscle mass by Matiegka and the formula AIN and unreliable direct medium strength $(r=0.37$ and $r=0.37)$ correlations with a width of mandible and an ectomorphic component of the somatotype of the Heath-Carter; return false medium strength ( $r$ from -0.31 to -0.40 ) correlations with the length of the body, with the height of the pubic, brachial points, with WDE of shoulder and leg, arm circumference of the lower third, circumference of the waist, wrist, chest on inspiration and expiration, with a transverse lower-sternal size and anteriorposterior size of the chest, with intertrochanteric size of pelvis, with TSFF on the front and back surfaces of the shoulder, chest, side, with endomorphic component of somatotype by Heath-Carter, with bone and fat masses by Matiegka;

rate the overall tone of the arteries - credible medium strength return ( $r$ from -0.41 to -0.51 ) correlations with TSFF under the shoulder blade, the abdomen, side, leg with endomorphic component somatotype by Heath-Carter and unreliable direct medium strength $(r=0.37)$ correlation with the width of the mandible; unreliable mean reciprocal force ( $r=-0.33$ and $r=-0.34)$ correlations with the WDE of the forearm, with the TSFF on the front of the shoulder;

indicator of large diameter arteries tone - reverse credible medium strength $(r=-0.53$ and $r=-0.50)$ correlations with TSFF on the side, leg and unreliable direct medium strength $(r=0.34)$ correlations with the width of the lower jaw; unreliable mean reciprocal force ( $r$ from -0.31 to -0.39 ) correlations with the height of the trochanteric point, with the girth of the thigh, with the TSFF under the shoulder blade, on the abdomen, thigh, with the endomorphic component of the somatotype by Heath-Carter;

the indicator of the tone of the arteries of medium and small diameter - reliable average reciprocal force ( $r$ from 0.45 to -0.48 ) correlations with the TSFF under the shoulder blade, on the abdomen, side, tibia, with the endomorphic component of the somatotype according to Heath-Carter, and also the unreliable mean force direct $(r=0.36$ and $r=$ 0.35 ) correlations with the width of the mandible and face; unreliable mean reciprocal force ( $r$ from -0.30 to -0.40 ) correlations with the WDE of forearm, with the TSFF on the back of the shoulder, with a fat mass by Matiegka;

indicator of the ratio of tone of arteries of different diameters - reliable average power straight $(r=0.47)$ correlations with the WDE of the forearm; unreliable mean reciprocal force $(r=-0.36$ and $r=-0.31)$ correlations with the width of the face and the shin circumference in the upper third.

\section{Discussion}

The system of cerebral circulation is characterized by relative independence from the general blood circulation. This is due to the presence of structural features of the structure of the vascular network, as well as regional mechanisms for maintaining cerebral circulation at an optimal level [5, 16, 30]. Against the background of increased interest in the study of the features of cerebral circulation in different age-sex contingents, very few studies devoted to the consideration of constitutional features of cerebral hemodynamics in practically healthy people [7].

Domestic and foreign researchers made an analysis of the correlations of rheoencephalographic indices with the data of general anthropometry and somatotype as the combined parameters of physical status and functional parameters of the vessels of the brain $[3,6,17,26,27]$. The most important in the search for morphogenetic condition of conditions and diseases of cerebral vessels from the scientific and practical point of view is the establishment of the relationship of rheoencephalographic indices with the ratio of individual components of the body [26, 27, 32]. It is known that the formation of components of the somatotype and the components of the body composition (in particular, the bone mass of the individual parts of the skeleton, skull) and the vessels of the head are determined by the same genetic mechanisms, but their conjugation and significance in neurological practice is not proved [32]

Thus, in analyzing the peculiarities of reliable correlations of the indicators of cerebral circulation with the constitutional parameters of the body of practically healthy young men of Podillia of the ectomorphic somatotype, we established the following multiple correlations: direct, reliable mean forces ( $r$ from 0.41 to 0.52 ) and unreliable average forces ( $r$ from 0.30 to 0.38 ) correlations of most amplitude indices (with the exception of the base impedance) with the head girth and the greatest length of the head, as well as the reversible, mostly unreliable, average forces ( $r$ from -0.30 to -0.40 ) and reliable the average strength ( $r$ from -0.41 to -0.53 ) correlations of most amplitude indices with the majority of total body sizes (with the exception of the incisure and diastolic wave amplitude), half of the WDE indices, most limbs girth (except for the base impedance), one third of 
the indicators of the TSFF (with the exception of the incidence amplitude), the muscular component of the body mass using the methods of Matiegka and AIN (with the exception of the base impedance) and bone and fat components of the body mass using the Matiegka method (only for the basic impedance); direct, mostly unreliable, average strength ( $r$ from 0.33 to 0.38 ), correlations of the duration of the cardiac cycle and the time of the downward part of the rheogram with half of the TSFF indices and the endomorphic component of the somatotype (only for the time of the downward part of the rheogram); direct, mostly unreliable, average forces ( $r$ from 0.30 to 0.37 ) correlations of the dicrotic index with a third of the indices of the TSFF and the endomorphic component of the somatotype, as well as the inverse of reliable average forces ( $r$ from -0.40 to -0.58 ) and unreliable mean force ( $r$ from -0.30 to -0.40 ) correlations of the average speed of fast and slow blood filling with all total, half of the longitudinal body size, half of the WDE indexes, the majority of circumferential body sizes, more than half the body diameters, most of the indicators of the TSFF, the endomorphic component of somatotype and all indicators of the body mass component composition and the inverse, mostly reliable, average strength ( $r$ from -0.41 to -0.51 ) correlations of the index of tone of all arteries, the tone of arteries of large diameter and the tone of arteries of medium and small diameter with more than half of the TSFF indices and endomorphic component of the somatotype. Attention is drawn to the lack of reliable and average force of false correlations: amplitudes indices with longitudinal dimensions of the body; time indices with total, longitudinal body dimensions and indicators of the component composition of body mass.

Quantitative analysis of correlations of cerebral circulatory parameters with constitutional body indicators in practically healthy young men from Podillia with ectomorphic somatotype showed the following distribution of correlations of amplitude, time and derivative indices rheoencephalogramm: 95 possible correlations of 285 (33.3\%) with the amplitude parameters (of which $1.4 \%$ of reliable direct average forces, $2.5 \%$ of the unreliable direct average forces, $1.1 \%$ of the true reverse strong, $10.2 \%$ of the true reciprocal average strength, $18.2 \%$ of the unreliable reciprocal average strength); 32 out of 285 possible (11.2\%) with time indicators (of which, $2.8 \%$ of the reliable direct average forces, $4.9 \%$ of the unreliable direct average forces, $0.6 \%$ of the reliable reciprocal average forces, $2.8 \%$ of the unreliable reciprocal average forces); 115 correlations from 456 possible $(25.2 \%)$ with derivatives indicators (of which, $0.9 \%$ are reliable direct average forces, $2.9 \%$ are false direct average forces, $10.7 \%$ are reliable reciprocal average forces, $10.7 \%$ unreliable reciprocal average forces).

Quantitative analysis of correlations of cerebral blood flow with constitutional parameters of the body of practically healthy young men of Podillia of the ectomorphic somatotype revealed the following distribution among the anthroposomatotypological parameters: with amplitude indicators - cephalometric indices $(12-34.3 \%$ of the total number of these indicators, of which $11.4 \%$ of reliable direct averages force, $20.0 \%$ of false direct middle forces, $2.9 \%$ of false reciprocal average forces); total body sizes (10 - 66.7\% of the total number of these indicators, of which $13.3 \%$ of the true reciprocal average strength, $53.3 \%$ of unreliable reciprocal average strength); WDE (9-45.0\% of the total number of indicators, of which $10.0 \%$ of the true reciprocal average strength, $35.0 \%$ of the unreliable reciprocal average strength); body diameters (8 $-22.9 \%$ of the total number of these indicators, of which $2.9 \%$ are reliable reverse strong, $8.6 \%$ reliable average reciprocal strength, $11.4 \%$ unreliable reciprocal average strength); girth dimensions of the body (26 $-34.7 \%$ of the total number of these indicators, of which $2.7 \%$ of the true reverse strong, $14.7 \%$ of the true reciprocal average force, $20.0 \%$ of the unreliable reciprocal average strength); TSFF (15 - 33.3\% of the total number of these indicators, of which $4.4 \%$ of the true reciprocal average strength, $28.9 \%$ of the false reciprocal average strength); components of the somatotype (3-20.0\% of the total number of indicators; all unreliable reciprocal average forces); components of the body mass index (12-60.0\% of the total number of indicators, of which $45.0 \%$ of the true reciprocal average strength, $15.0 \%$ of unreliable reciprocal average strength). With time indicators - cephalometric indices (10 $28.6 \%$ of the total number of these indicators, of which $8.6 \%$ of reliable direct average forces, $5.7 \%$ of unreliable direct average forces, $2.9 \%$ of reliable reciprocal average forces, $11.4 \%$ of unreliable reciprocal average forces); WDE (1 $5.0 \%$ of the total number of indicators, all reliable reciprocal average strength); body diameters (5-14.3\% of the total number of these indicators, of which $2.9 \%$ are reliable direct average forces, $8.6 \%$ of false direct average forces, $2.9 \%$ of false reciprocal average forces); girth sizes of the body (5 $6.7 \%$ of the total number of these indicators, of which $4.0 \%$ of false direct average forces, $2.7 \%$ of false reverse average strength); TSFF (10 - 22.2\% of the total number of these indicators, of which $8.9 \%$ are reliable direct average forces, $11.1 \%$ are false direct average forces, $2.2 \%$ are unreliable reciprocal average strength); components of the somatotype ( $1-6.7 \%$ of the total number of these indicators; all unreliable direct mean power). With derived indicators - cephalometric indices (10 - $20.8 \%$ of the total number of these indicators, of which $4.2 \%$ are reliable direct average forces, $12.5 \%$ are false direct middle forces, $2.1 \%$ are reliable reciprocal average forces, $2.1 \%$ are unreliable reciprocal average forces); total body sizes (6 - 25.0\% of the total number of these indicators, of which $20.8 \%$ of the true reciprocal average force, $4.2 \%$ of the unreliable reciprocal average strength); longitudinal body dimensions ( $6-15.0 \%$ of the total number of indicators; all unreliable reciprocal average forces); WDE ( $8-25.0 \%$ of the total number of these indicators, of which $3.1 \%$ of the reliable direct average strength, $9.4 \%$ of the true reciprocal average strength, $12.5 \%$ of the unreliable reciprocal average strength); body diameters (10 - 17.9\% of the total number of these indicators, of which $5.4 \%$ of the 
true reciprocal average strength, $12.5 \%$ of false reverse average strength); circumferential body dimensions (25 $20.8 \%$ of the total number of these indicators, of which $0.8 \%$ are false direct average forces, $10.8 \%$ of the true reciprocal average strength, $9.2 \%$ of false reverse average strength); TSFF (34 - 47.2\% of the total number of these indicators, of which $1.4 \%$ are reliable direct average forces, $5.6 \%$ of unreliable direct average forces, $20.8 \%$ of the true reciprocal average strength, $19.4 \%$ of false reciprocal average forces); components of the somatotype (7-29.2\% of the total number of these indicators, of which $8.4 \%$ are false direct average forces, $12.5 \%$ of the true reciprocal average strength, $8.4 \%$ of the unreliable reciprocal average strength); components of the body weight ( $9-28.1 \%$ of the total number of indicators, of which $18.8 \%$ of the true reciprocal average strength, $9.4 \%$ of the unreliable reciprocal average strength).

It should be noted that in the general group of practically healthy young men of Podillia, the highest number of reliable correlations has been established: among the amplitude indicators - mostly direct with amplitude of incisure; among the time indices - mainly direct with the duration of the ascending part, the phase of fast and slow blood flow of the rheograms, and mostly reversed with the duration of the downward part of the rheogram; among the derivatives mostly reverse with the dicrotic index and the average speed of fast and slow blood flow of the rheograms and, mainly direct, with tone indices of all arteries and arteries of large, medium and shallow diameters [13].

In practically healthy young men of Podillia of mesomorphic somatotype among all groups of indicators of cerebral blood circulation, the greatest number of reliable correlations established with constitutional parameters of the body for time indices - mainly with total, longitudinal, circumflex body dimensions, indicators of body composition, WDE and cephalometric indices, respectively, for amplitude

\section{References}

[1] Alekseev, V. P., \& Debets, G. F. (1964). Craniometry: anthropological research methodology. M.: Science.

[2] Amlie-Lefond, C., Bernard, T. J., Sebire, G., Friedman, N. R., Heyer, G. L., Lerner, N. B., ... Fullerton, H. J. (2009). Predictors of Cerebral Arteriopathy in Children with Arterial Ischemic Stroke. Circulation, 119(10), 1417-1423. https://doi.org/ 10.1161/CIRCULATIONAHA.108.806307

[3] Bobrovska, O. A. (2008). Features of correlations between total body parameters in urban adolescents-ectomorphs, mesomorphs and ecto-mesomorphs with central hemodynamics indices. Reports of morphology, 14(1), 78-82.

[4] Bodo, M. (2010). Studies in Rheoencephalography (REG). J. Electr. Bioimp, 1, 18-40. doi: http://dx.doi.org/10.5617/jeb.109

[5] Bodo, M., Pearce, F., Garcia, A., Van Albert, S., Settle, T., Szebeni, J., ... Armonda, R. (2010). In vivo cerebral blood flow autoregulation studies using rheoencephalography. Journal of Physics: Conference Series, 224(1), 4. doi:10.1088/17426596/224/1/012088. doi: 10.1088/1742-6596/224/1/012088

[6] Bogachuk, O. P. (2006). Correlation relations of indicators of cerebral blood circulation with the development of adipose tissue and somatotypological indicators in urban teenagers of Podillia. Biomedical and Biosocial Anthropology, 7, 126-130. indices of rheograms - with body diameters, cephalometric indices, components of somatotype and components of component composition body weight; and for derivative indicators - with longitudinal, total, circumflex body dimensions and indicators of the component composition of body mass [14].

Thus, studies of correlations of rheoencephalographic parameters with body sizes complement existing perceptions about the peculiarities of the functional organization of hemodynamic processes in brain basins in practically healthy young men of the ectomorphic somatotype, which allow more accurately to differentiate the norm and pathology, as well as to improve the quality and effectiveness of the treatment of various vascular pathologies of the brain.

\section{Conclusions}

1. In the practically healthy young men of the ectomorphic somatotype, among the all groups of indicators of cerebral circulation, the largest number, mostly reverse valid and unreliable average strength, correlations with anthropomorphic somatotypological indicators was established for amplitude indices $(33.3 \%)$ - with total body sizes $(66.7 \%$ of the total number of these indicators), components of body mass $(60.0 \%)$, WDE $(45.0 \%)$, circumferential body size $(34.7 \%)$, cephalometric indices (34.3\%) and TSFF (33.3\%).

2. The largest number, mostly inverse, of reliable and unreliable average strength correlations, was found for derivative indicators $(25.2 \%)$ - with TSFF $(47.2 \%$ of the total number of these indicators), somatotype components (29.2\%), components of body mass index (28.1\%), total body size and WDE (by 25.0\%); and, mainly direct, inaccurate average strength correlations, for time indices (11.2\%) was established - with cephalometric indices $(28.6 \%$ of the total number of these indicators), TSFF $(22.2 \%)$ and body diameters $(14.3 \%)$.

[7] Bogachuk, O. P., \& Shevchenko, V. M. (2007). Changes in the parameters of the rheoencephalogram in urban adolescents in the Podillia region of Ukraine, depending on the characteristics of the somatotype. Biomedical and Biosocial Anthropology, 8, 45-49.

[8] Bor-Seng-Shu, E., Kita, W. S., Figueiredo, E. G., Paiva, W. S., Fonoff, E. T., Teixeira, M. J., \& Panerai, R. B. (2014). Cerebral hemodynamics: concepts of clinical importance. Arq. Neuropsiquiatr., 70(5), 352-356. PMID: 22618788

[9] Brouwn, M., \& Dichgans, M. (2011). Advances in stroke in the young. Abstracts presented at 15 th Congress of the Federation of Neurological Societies, Budapest (p. 51). Budapest.

[10] Bunak, V. V. (1941). Anthropometry: a practical course. M.: Uchpedgiz.

[11] Carter, J. L., \& Heath, B. H. (1990). Somatotyping-development and applications. Cambridge University Press.

[12] Chromoвa, A. V., Curochkina, Ye. L., \& Bebyakova, N. A. (2011). Constitutional aspects of systemic hemodynamics in the European North. Abstracts are presented in the materials of the international scientific-practical conference "Circumpolar medicine: the influence of environmental factors on the 
formation of human health", Arkhangelsk (pp. 300-303). Arkhangelsk: Publishing of Northern State Medical University.

[13] Datsenko, G. V., Dmitrenko, S. V., \& Serebrennikova, O. A. (2017). Relations rheoencephalography indicators with constitutional parameters of a body of practically healthy young from Podillya. Bulletin of Vinnitsa National Medical University, 21, 1(2), 244-247.

[14] Datsenko, G. V., Shayuk, A. V., Dzevulska, I. V., Kyselyova, T. M., \& Kyrychenko, V. I. (2018). Features of correlations of cerebral circulation indicators with anthroposomatotypological parameters of the body in practically healthy young men of mesomorphic somatotype. Biomedical and biosocial anthropology, 32, 13-20. doi: 10.31393/bba32-201802

[15] Fanning, J. P., Wong, A. A., \& Fraser, J. F. (2014). The epidemiology of silent brain infarction: a systematic review of population-based cohorts. BMC Med., 12, 119. doi: 10.1186/ s12916-014-0119-0

[16] Goadsby, P. J. (2013). Autonomic nervous system control of the cerebral circulation. Handb. Clin. Neurol., 117, 193-201. doi: 10.1016/B978-0-444-53491-0.00016-X

[17] Koleva, M., Nacheva, A., \& Boev, M. (2002). Somatotype and disease prevalence in adults. Rev. Environ. Health., 17(1), 65-84. PMID: 12088094

[18] Krejza, J., Arkuszewski, M., Kasner, S. E., Weigele, J., Ustymowicz, A., Hurst, R. W., ... Messe, S. R. (2006). Carotid Artery Diameter in Men and Women and the Relation to Body and Neck Size. Stroke, 37(4), 1103-1105. doi: 10.1161/ 01.STR.0000206440.48756.f7

[19] Magomedov, A. M., \& Shcherbakova, I. V. (2015). Use of statistical methods in medical research. Bulletin of Medical Internet Conferences, 4(11), 1270-1271.

[20] Matiegka, J. (1921). The testing of physical effeciecy. Amer. J. Phys. Antropol., 2(3), 25-38. https://doi.org/10.1002/ ajpa.1330040302

[21] Moskalenko Yu. E., \& Andreeva, Ju. V. (2015). Rheoencephalography: past popularity, obvilion at present and optimistic furure. International Journal of Advances in Life Science and Technology, 2(1), 1-15. doi: 10.18488/journal.72/ 2015.2.1/72.1.1.15

[22] Moskalenko, Yu. E., Vardy, T. M., Sabirov, A., Kravchenko, T. I., Riabchikova, N. A., \& Uglova, N. N. (2016). Quantitative Analysis of Intracranial Volume Slow-Wave Fluctuations. Academic Journal of Life Sciences, 2(8), 50-60.

[23] Nurmetova, I. K., \& Kuhar, I. D. (2010). Characteristics of correlations of anthropometric parameters of adolescents with indicators of rheoencephalography, depending on somatotype. Reports of morphology, 16(4), 887-890.

[24] Razmologova, O. Yu., \& Medvedev, Yu. A. (2009). Constitutional variants of the structure of the arterial ring of the brain and their role in the development and aneurysmal disease. Pathology Archive, 71(6), 33-35.

[25] Sarafinyuk, L. A. (2008). Somatotypological features of the indicators of central hemodynamics, obtained by tetrapolar reocardiogram, in girls and boys of adolescence age. Scientific notes of the Ternopil National Pedagogical University named after Volodymyr Hnatyuk, 4(38), 72-79.

[26] Schankin, A. A, \& Kosheleva, O. A. (2012). Influence of the constitutional type of age evolution of girls on the volumetric blood flow of the brain. Siberian Medical Journal, 27(1), 9094.

[27] Semenchenko, V. V. (2016). Correlation of the constitutional parameters of the body of practically healthy women of the division of the mesomorphic somatotype with the parameters of cerebral circulation. Biomedical and Biosocial Anthropology, 27, 49-52.

[28] Shephard, R. J. (1991). Body composition in biological anthropology. Cambridge.

[29] Tatlisumak, N. (2011). The long-term prognosis of ischemic stroke in the young - is it really favourable? Abstracts presented at 15 th Congress of the Federation of Neurological Societies, Budapest (pp. 1-17). Budapest.

[30] Ter Laan, M., van Dijk, J. M. C., \& Elting, J. W. J. (2013). Sympathetic regulation of cerebral blood flow in humans: $A$ review. Brit. J. Anaesth., 111(3), 161-167. doi: 10.1093/bja/ aet122

[31] Tsai, C. F., Thomas, B., \& Sudlow, C. L. (2013). Epidemiology of stroke and its subtypes in Chinese vs white populations: a systematic review. Neurology, 81(3), 264-72. doi: 10.1212/ WNL.0b013e31829bfde3

[32] Vilchinskaya, L. P. (2014). Characteristics of the fatty component of the somatotype of women who have suffered vascular diseases of the brain. Abstracts are published in the materials of the scientific conference dedicated to the memory of associate professor N. G. Nazimova "Spring anatomical readings", Grodno (p. 34-45). Grodno: GrSMU.

[33] Zelinsky, B. O., Zlepko, S. M., Kostenko, M. P., \& Kovalchuk, B. M. (2000). Portable multifunctional device for diagnosing the vascular bed of the circulatory system. Measuring and computing engineering in technological processes, 1, 125-132.

\section{КОРЕЛЯЦІЇ ПОКАЗНИКІВ ЦЕРЕБРАЛЬНОГО КРОВООБІГУ 3 АНТРОПОМЕТРИЧНИМИ РОЗМІРАМИ ПРАКТИЧНО ЗДОРОВИХ ЮНАКІВ ЕКТОМОРФНОГО СОМАТОТИПУ}

Даценко Г. В., Смолко Д. Г., Макарчук І. М., Слабий О. Б., Прокопенко С. В.

В сучасній науковій літературі переважна більшість досліджень присвячена вивченню особливостей мозкового кровообігу у представників різних віково-статевих груп, а дослідження, присвячені конституціональним особливостям иеребральної гемодинаміки у практично здорового населення практично відсутні. Мета роботи - встановити кореляції показників церебрального кровообігу з антропо-соматотипологічними параметрами тіла практично здорових юнаків Поділля ектоморфного соматотипу. На базі науково-дослідного центру Вінницького національного медичного університету ім. М. І. Пирогова проведені реоениесалографрічні, антропометричні та соматотипологічні дослідження 24 практично здорових міських юнаків Подільського регіону України ектоморфного соматотипу. Аналіз кореляцій проводили з використанням непараметричного методу Спірмена в ліцензійному статистичному пакеті "Statistica 6.1". У практично здорових юнаків ектоморфного соматотипу встановлені наступні множинні зв'язки показників церебрального кровообігу 3 конституціональними параметрами тіла: прямі достовірні (r від 0,41 до 0,52) і недостовірні середньої сили (r від 0,30 до 0,38) зв'язки більшості амплітудних показників з обхватом голови й найбільшою довжиною голови, а також зворотні, переважно недостовірні ( $r$ від -0,30 до -0,40), і достовірні середньої сили (r від -0,41 до -0,53) зв'язки з більшістю тотальних розмірів тіла, половиною показників ширини дистальних епіфізів довгих трубчастих кісток кінцівок (ШДЕ), більшістю обхватів кінцівок, третиною показників товщини шкірно-жирових складок (ТШЖС), показниками компонентного складу 
маси тіла; прямі, переважно недостовірні, середньої сили ( $r$ від 0,33 до 0,38) зв'язки тривалості серцевого циклу й часу низхідної частини реограми з половиною показників ТШжС; прямі, переважно недостовірні, середньої сили ( $r$ від 0,30 до 0,37) зв'язки дикротичного індексу з третиною показників ТШЖС і ендоморфним компонентом соматотипу, а також зворотні достовірні (r від -0,40 до -0,58) і недостовірні середньої сили ( $r$ від -0,30 до -0,40) зв'язки середньої швидкості швидкого й повільного кровонаповнення з усіма тотальними, половиною поздовжніх розмірів тіла, половиною показників ШДЕ, більшістю обхватних розмірів тіла, більш ніж половиною діаметрів тіла, більшістю показників ТШЖС, ендоморфним компонентом соматотипу й усіма показниками компонентного складу маси тіла та зворотні, переважно достовірні, середньої сили ( $r$ від -0,41 до -0,51) зв'язки показника тонусу всіх артерій, тонусу артерій великого, а також середнього та мілкого діаметра $з$ більш ніж половиною показників ТШжС й ендоморфрним компонентом соматотипу. При аналізі кореляцій показників реоенцефралограми з конституціональними параметрами тіла у практично здорових юнаків ектоморфного соматотипу найбільшу кількість, переважно зворотних достовірних і недостовірних середньої сили, зв'язків встановлено для амплітудних показників - з тотальними розмірами тіла (66,7\% від загальної кількості даних показників), показниками компонентного складу маси тіла (60,0\%), ШДЕ (45,0\%), обхватними розмірами тіла (34,7\%), кефралометричними показниками (34,3\%) та ТШЖС (33,3\%). Найбільша кількість, переважно зворотних достовірних і недостовірних середньої сили зв'язків, для похідних показників встановлена - з ТШЖС (47,2\% від загальної кількості даних показників), компонентами соматотипу (29,2\%), показниками компонентного складу маси тіла (28,1\%), тотальними розмірами тіла та ШДЕ (по 25,0\%); а, переважно прямих недостовірних середньої сили зв'язків, для часових показників встановлена - з кефалометричними показниками (28,6\% від загальної кількості даних показників), ТШЖС (22,2\%) та діаметрами тіла (14,3\%).

Ключові слова: кореляції, реоенцефралографрія, антропометрія, ектоморфний соматотип, практично здорові юнаки.

КОРРЕЛЯЦИИ ПОКАЗАТЕЛЕЙ МОЗГОВОГО КРОВООБРАЩЕНИЯ С АНТРОПОМЕТРИЧЕСКИМИ РАЗМЕРАМИ ПРАКТИЧЕСКИ ЗДОРОВЫХ ЮНОШЕЙ ЭКТОМОРФНОГО СОМАТОТИПА

Даценко Г. В., Смолко Д. Г., Макарчук И. Н., Слабый О. Б., Прокопенко С. В.

В современной научной литературе подавляющее большинство исследований посвящено изучению особенностей мозгового кровообращения у представителей разных возрастно-половых групп, а исследования, посвященные конституциональным особенностям церебральной гемодинамики у практически здорового населения, практически отсутствуют. Цель работы - установить корреляции показателей мозгового кровообращения с антропо-соматотипологическими параметрами тела практически здоровых юношей Подолья эктоморфного соматотипа. На базе научно-исследовательского центра Винницкого национального медицинского университета им. Н. И. Пирогова проведены реоэнцефралографические, антропометрические и соматотипологические исследования 24 практически здоровых городских юношей Подольского региона Украины эктоморфрного соматотипа. Анализ корреляций проводили с использованием непараметрического метода Спирмена $в$ лицензионном статистическом пакете "Statistica 6.1". У практически здоровых юношей эктоморфного соматотипа установлены следующие множественные связи показателей мозгового кровообращения с конституциональными параметрами тела: прямые достоверные ( $r$ om 0,41 до 0,52) и недостоверные средней силы (r om 0,30 до 0,38) связи большинства амплитудных показателей с охватом головы и наибольшей длиной головы, а также обратные, преимущественно недостоверные (r om -0,30 до -0,40), и достоверные средней силы (r om -0,41 до -0,53) связи с большинством тотальных размеров тела, половиной показателей ширины дистальных эпифизов длинных трубчатых костей конечностей (ШДЭ), большинством обхватов конечностей, третью показателей толщины кожно-жировых складок (ТКЖС), показателями компонентного состава массы тела; прямые, преимущественно недостоверные, средней силы (r om 0,33 до 0,38) связи продолжительности сердечного цикла и времени нисходящей части реограммы с половиной показателей ТКжС; прямые, преимущественно недостоверные, средней силы ( $r$ om 0,30 до 0,37) связи дикротического индекса с третью показателей ТКЖС и эндоморфным компонентом соматотипа, а также обратные достоверные ( $r$ от $-0,40$ до -0,58) и недостоверные средней силы (r om -0,30 до -0,40) связи средней скорости быстрого и медленного кровенаполнения со всеми тотальными, половиной продольных размеров тела, половиной показателей ШДЭ, большинством обхватных размеров тела, более чем половиной диаметров тела, большинством показателей ТКЖС, эндоморфным компонентом соматотипа и всеми показателями компонентного состава массы тела и обратные, преимущественно достоверные, средней силы (r om -0,41 до -0,51) связи показателя тонуса всех артерий, тонуса артерий крупного, а также среднего и мелкого диаметра с более чем половиной показателей ТКЖС и эндоморфным компонентом соматотипа. При анализе корреляций показателей реоэнцефралограммы с конституциональными параметрами тела у практически здоровых юношей эктоморфного соматотипа наибольщее количество, преимущественно обратных достоверных и недостоверных средней силы связей установлено для амплитудных показателей - с тотальными размерами тела (66,7\% от общего количества данных показателей), показателями компонентного состава массы тела (60,0\%), ШДЭ (45,0\%), обхватными размерами тела (34,7\%), кералометрическими показателями (34,3\%) и ТКЖС (33,3\%). Наибольшее количество, преимущественно обратных достоверных и недостоверных средней силы связей, для производных показателей установлена - c TKЖС (47,2\% от общего количества данных показателей), компонентами соматотипа (29,2\%), показателями компонентного состава массы тела (28,1\%), тотальными размерами тела и ШДЭ (по 25,0\%); а преимущественно прямых недостоверных средней силы связей, для временных показателей установлена - с кефралометрическими показателями (28,6\% от общего количества данных показателей), ТКЖС (22,2\%) и диаметрами тела (14,3\%).

Ключевые слова: корреляции, реоэнцефалография, антропометрия, эктоморфный соматотип, практически здоровые юноши. 